\title{
UN LANCE DE DADOS PARA LEER DESPACIO: ENTRE STÉPHANE MALLARMÉ Y HERBERTO HELDER
}

\author{
A throw of the dice to read slowly: \\ between Stéphane Mallarmé and Herberto Helder
}

\author{
Marina Ribeiro Mattar* \\ Universidade Federal de Minas Gerais - Brasil \\ marina.rmattar@gmail.com
}

Palabras clave

Herberto Helder;

Stéphane Mallarmé;

silencio;

juego

Keywords

Herberto Helder;

Stéphane Mallarmé;

silence;

game

\section{Resumen}

Este breve ensayo se propone comparar las imágenes del mar, del vacío y del juego en los poemas Para o leitor ler de/vagar de Herberto Helder (1930-2015) y Un lance de dados jamás abolirá el azar de Stéphane Mallarmé (1842-1898). Además del campo semántico que crea una especie de silencio en los poemas, nos interesa comprender de qué manera ese mutismo actúa en sus estructuras y cuáles son sus posibles significados. El análisis se apoya en los trabajos críticos de Martelo (2010) y Campos (2002).

\begin{abstract}
This short essay proposes to compare the images of the sea, the void and the game in the poems Para o leitor ler de/vagar by Herberto Helder (1930-2015) and Un coup de dés jamais n'abolira le Hasard by Stéphane Mallarmé (1842-1898). In addition to the semantic field that creates a kind of silence in poems, we are interested in understand how this silence acts in the structure of the poems and its possible meanings. We support our analysis in the critical works of Martelo (2010) and Campos (2002), to justify our interpretations.
\end{abstract}




\section{Un lance de dados para leer despacio: entre Stéphane Mallarmé y Herberto Helder}

Este ensayo parte de la propuesta de Rosa María Martelo de que el poeta portugués Herberto Helder (1930-2015) expone "una idea de libro que evoca la concepción mallarmeana", sobre la cual se basa el "nodo energético" de su poesía, inseparable de un ritmo orgánico presente en el acto de escritura (2010, p. 90). De ahí la motivación para analizar las convergencias y divergencias entre los poemas "Un lance de dados jamás abolirá el azar" ("Un coup de dés jamais n'abolira le hasard”), del notable escritor francés Stéphane Mallarmé (1842-1898) y "Para que el lector lea d/espacio" ("Para o leitor ler de/vagar"), del referido autor portugués. ${ }^{1}$

Acercarse a Mallarmé y a Helder es concebir la escritura como un conjunto de "operaciones del lenguaje", aproximando el acto de escribir a las "subdivisiones prismáticas de la Idea”. Para Mallarmé, el texto lírico "más que un boceto, es un estado", al mismo tiempo, constituye la "única fuente para ciertas cuestiones de pura y compleja imaginación o intelecto” (Mallarmé, 2013, p. 2). De acuerdo al autor francés, el poema se convierte en el único camino, como se observa en un verso de Helder: "Tantos nomes que não há para dizer o silencio" - una manera de decir sin decir-, un camino que se encuentra en el silencio.

En ambos poetas hallamos el enigma, la imagen del silencio, la imposibilidad, la obra que no se acaba. Una imagen que se observa impresa en el espacio material gráfico del poema de Mallarmé y en el espacio corpóreo-semántico del texto de Helder.

Si en el poema de Helder "o erro está no coração do acerto”3 (2006b, p. 128), para Mallarmé, el error es el resultado de la experimentación natural, tal como lo explica en su prefacio: "esta tentativa participa, imprevistamente, de búsquedas singulares y caras a nuestra época: el verso libre y el poema en prosa" (en Campos, 2002, p. 152). Ambas estructuras poéticas, establecidas ya sólidamente en la tradición lírica en el momento en que Helder escribe, se convierten en su poema en instrumentos para reflexionar sobre su propia creación, en una apuesta por el acto de escribir sostenida por las dos estructuras del verso.

De acuerdo con Martelo (2010), la poesía de Helder y Mallarmé se vinculan en el uso de un lenguaje que existe para superar sus vacíos, sin embargo, no coinciden en que:

Para Mallarmé, hay un lenguaje poético que supera, principalmente por la relación entre sonido y significado, la arbitrariedad de los lenguajes. En Herberto Helder la pregunta parece ampliarse, porque no hay garantía de que la poética helderliana acepte la posibilidad de definir lo que, en términos esencialistas, es un lenguaje poético o el lenguaje de la poesía. (Martelo, 2010, p. 92-93)

1. Todas las traducciones al español incluidas en este artículo pertenecen a la autora.

2. "Tantos nombres que no hay para decir el silencio".

3. "el error está en el corazón del acierto". 
Entonces, ¿qué mecanismos emplean ambos escritores para garantizar el ritmo de sus poemas, sin apoyarse exclusivamente en los sonidos tónicos o átonos de las palabras? Mallarmé estima que la distancia (espacio en blanco) que separa las palabras o los grupos de palabras "parece acelerar y disminuir también el movimiento, acompasándolo, convocándolo, a causa de una visión simultánea de la página: entendida esta como unidad, como lo es en otra parte el verso o la línea perfecta" (2013, p. 2). Algo similar ocurre cuando Helder se refiere a la lectura errante (de/vagar). Los cortes en los versos sugieren pausas, divagaciones, vacíos, silencios, como en "As costas/das. Mãos". ${ }^{4}$ Así como múltiples significaciones en frases bruscamente interrumpidas, como: "luminos- idade" (Helder, 2006a, p. 126).

Para Campos, el poeta francés "inventa un proceso de organización poética" que se expresa mediante la palabra-estructura, en "oposición a la organización meramente lineal y aditiva tradicional del verso" (2002, p. 179). Además de los aspectos estructurales ya estudiados especialmente por los poetas concretistas brasileños del siglo pasado, el poema de Mallarmé propone también líneas temáticas que tienen ecos en "Para o leitor ler de/vagar" de Herberto Helder. Son evidentes las coincidencias en los campos semánticos de ambos textos. El de Mallarmé posee una fuerte presencia del tema marítimo con la imagen del naufragio. Asimismo, es posible el tópico pueda percibirse como resultado de la misma estructura espacial poemática. Naufragio como posibilidad de un lanzamiento de dados, como una empresa marítima que se descompone en "motivo primordial, motivo secundario y motivo adyacente", tal como explica Campos la estructura del poema (2002, p. 180).

La apreciación positiva del concepto de diferencia que hace la autora abre un abanico de pluralidades y posibilidades diversas de ser y habitar el mundo a la vez que sienta las bases para la lucha en contra de cualquier tipo de opresión (sexista, racista, patriarcal). Asimismo, se trata de un acto que favorece el desarrollo de relaciones interpersonales más ricas en las que se considera a las personas en sus complejidades. Finalmente, las reflexiones de Lorde en torno al concepto de diferencia terminaron siendo un aporte fundamental y decisivo al movimiento feminista.

Sin embargo, se podría establecer una distinción crucial entre los dos textos. En el poema de Mallarmé, se observa una extensión del pensamiento poético, pero como se lee en el prefacio: "se evita el relato" (2002, p. 151). En el de Helder, por su parte, se percibe un fuerte tono narrativo, aunque paradójico. Al principio, por el tono epistolar, de confesión; luego, porque el sujeto lírico se refiere a un mundo interior. El caso es que se trata de una "historia sin poros" y cuanto más gira el sujeto lírico en su interior, en un intento de hablar de sí mismo, menos es capaz de penetrar el lector.

El sujeto lírico inicia el poema pareciendo analizar tanto su condición de sujeto como su propio ritmo: "Lector: soy lento", en franco diálogo con el receptor. Pero la experiencia del ritmo es también una experiencia corporal, posteriormente se verifica que ese sujeto lírico está encerrado en un sustantivo ("como una piedra") que solo puede ser adjetivado ("piedrísima") por su propia naturaleza:

4. "Las costas/de las. Manos".

5. "lumino- sidad". Traducción de la autora. 


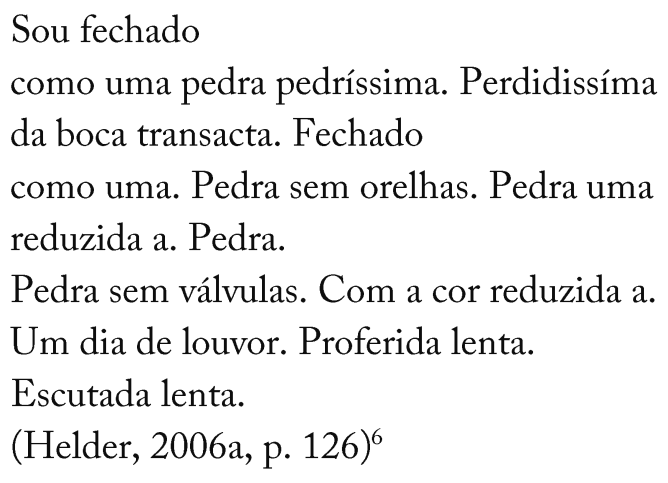

Martelo (2010) estudiando otro poema de Helder, destaca un tema que parece atravesar gran parte de la obra del autor portugués:

La relación entre sujeto y mundo se sitúa en el plano de las intensidades magnificadas de ambos; sucede por el ritmo orgánico (...), no puede ser más que una imagen de la indiscreción entre una energía (no verbal) y la experiencia que le da reflexividad (verbalización). (Martelo, 2010, p. 97)

Así, la "energía" no verbal de los cortes, espacios y silencios se confunde con la verbalización de la experiencia material de uno mismo, porque se presenta herméticamente, porque es impenetrable. La idea del juego, también visible en Mallarmé, con el verso que "cierra” el poema: “Todo pensamiento emite un lance de dados", es llevada al extremo por Helder, en tanto el poeta tira los dados (escribe), pero no deja que se vea el resultado de sus "lances", solo queda la experiencia del acto lúdico de la escritura. No hay salida del poema, el poema es la salida.

Helder toma prestada la "constelación" del poeta francés en los versos: "Este livro apertado nas estrelas/ da boca, estrellas". ${ }^{7}$ No obstante, las estrellas son miembros cerrados. Existen para que el poeta pueda escribirlas: "batê-las durante o tempo./ Eterno, o tempo./ De uma onda maior que nosso tempo"8 (2006a, p. 131). De ese modo, el acto de escribir, que es el lanzamiento de los dados en sí, se equipara al movimiento del mundo develado en los dos poemas, movimiento que posibilita la creación.

Con los versos de Helder: "As ondas de Deus auxiliado/auxiliar" (2006a, p. 129), ${ }^{9}$ nos preguntamos: ¿Quién estaría ayudando a Dios? ¿Y a quién él ayuda? Si al poeta lo ayuda Dios, entonces el azar forma parte del poema. Ahora, volviendo a Mallarmé en "Un lance de dados jamás abolirá el azar”, cabría preguntarse: ¿sería posible concebir que la poesía sea un lance de dados, donde Dios auxilia al poeta ofreciéndole material de escritura? ¿Sería el azar el que le proporciona el ritmo

\footnotetext{
6. "Soy cerrado/como una piedra piedrísima./ Perdidisíma/ de la boca tramitada. Cerrado como una./ Piedra sin orejas./ Piedra una/ reducida a./ Piedra./ Piedra sin válvulas./ Con el color reducido/ a./ Un día de culto./ Proferida lenta./ Escuchada lenta".

7. "Este libro apretado en las estrellas/ de la boca, estrellas".

8. "golpearlas durante el tiempo. /Tiempo eterno. Una ola más grande que nuestro/tiempo".

9. "Las olas de Dios ayudado/ ayudante".
} 
al poeta, al poema, al libro y a la vida? Aún más, ¿este movimiento contradictorio, revelaría una escritura que, al pretender hablar de sí misma, opta por esconderse?

Sin respuestas a tales cuestiones, además de las hipótesis planteadas en este ensayo, el poema de Helder solo puede navegarse con el ritmo lento que sugiere, desde el nivel semántico hasta el gráficovisual. Para Rezende, en Helder, "la revelación que debe entenderse desde su resiliencia formal es: no hay contenido por debajo o más allá del discurso mismo" (2018, p. 137). Contra la carne y contra el tiempo el poeta escribe versos. Al crítico/lector le corresponde caminar, andar lentamente, aprender a entender el azar y tirar los dados con la obra de estos grandes poetas: Helder y Mallarmé.

\section{Referencias bibliográficas}

Campos, A. de; Pignatari, D. y Campos, H. de (2002). Mallarmé. São Paulo, Perspectiva.

Campos, A. de. (2002). Poesia, Estrutura. En Campos, A. de; Pignatari, D. y Campos, H. de. Mallarmé (pp. 177-180). São Paulo, Perspectiva.

Helder, H. (2006a). Ou o poema continuo. São Paulo, A Girafa Editora.

Helder, H. (2006b). Photomaton E Vox. Lisboa, Assírio \& Alvim.

Mallarmé, S. (2013). Un lance de Dados jamás abolirá el Azar (J. Segovia, trad.). Paris, Maldoror Ediciones.

Martelo, R. M. (2010). A forma informe: leituras de poesia. Lisboa, Assírio \& Alvim.

Rezende, C. A. de (2018). Arqueologia da forma [manuscrito]: Herberto Helder, Nuno Ramos e Paulo Henriques Britto [Tesis de Doctorado en Literatura]. Belo Horizonte, Universidade Federal de Minas Gerais.

* Marina Ribeiro Mattar es Magíster en Estudios del Lenguaje (CEFET-MG) y doctoranda en el Programa de Estudios Literarios de la UFMG, en Belo Horizonte, Minas Gerais/Brasil. Estudia poesía moderna y contemporánea y su relación con las formas del libro.

RECIBIDO: $27 / 10 / 2020$

ACEPTADO: 27/01/2021 